\title{
Teaching NeuroImages: Reversible neuroimaging findings during treatment of infantile spasms with vigabatrin
}

David Dongkyung Kim, MD, Amit Kumar Sharma, MD, Manas Sharma, MD, and Andrea Andrade, MD Neurology ${ }^{\circledR}$ 2020;95:e2314-e2315. doi:10.1212/WNL.0000000000010370

Figure Reversible abnormal MRI findings during treatment of infantile spasms with vigabatrin

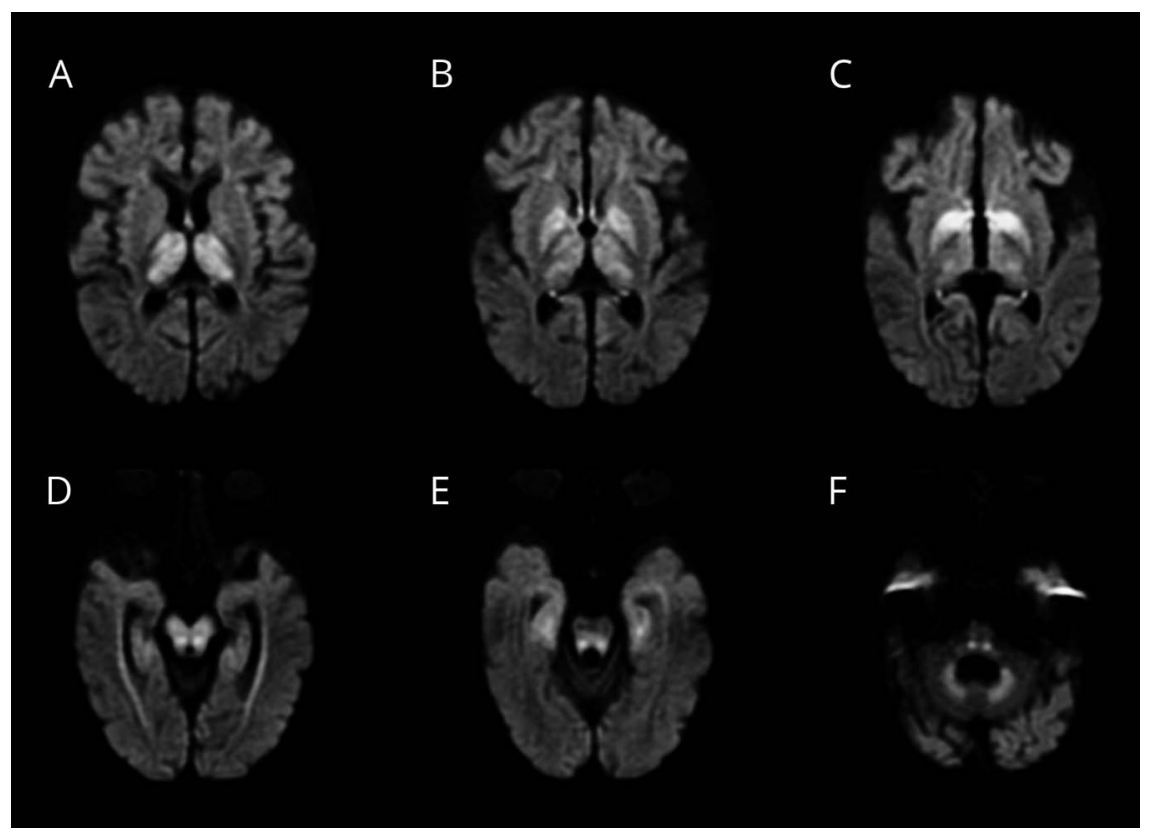

Diffusion-weighted imaging showed symmetrical signal change in bilateral thalami (A, B), globus pallidi (B, C), cerebral peduncles (D), central tegmental tracts (D-F), and dentate nuclei (F). Apparent diffusion coefficient maps showed corresponding changes (not pictured). Follow-up imaging 4 months later showed resolution of the changes seen earlier (not pictured).

A 10-month-old boy with global developmental delay presented to clinic with a few months of infantile spasms occurring multiple times a day. His seizures continued despite vigabatrin (dosed at $133 \mathrm{mg} / \mathrm{kg} / \mathrm{d}$ ), levetiracetam, and steroid therapy. On vigabatrin, routine follow-up MRI showed abnormal signal change (figure), which may occur in $30.9 \%$ of patients. ${ }^{1}$ Risk is associated with a high peak dose but not cumulative. ${ }^{2}$ These findings are largely asymptomatic although rarely patients can present with hyperkinetic disorders. ${ }^{2}$ The imaging findings resolved on 4-month follow-up after tapering vigabatrin. At 18 months of age, the patient continues to have 1 seizure every 2 weeks.

\section{Correspondence}

Dr. Kim

david.kim@medportal.ca
MORE ONLINE

$\rightarrow$ Teaching slides

links.lww.com/WNL/

B176

From the Department of Clinical Neurological Sciences (D.D.K., A.K.S.), Division of Neuroradiology, Department of Radiology (M.S.), and Division of Pediatric Neurology, Department of Pediatrics (A.A.), Western University, London, Canada.

Go to Neurology.org/N for full disclosures. Funding information and disclosures deemed relevant by the authors, if any, are provided at the end of the article. 


\section{Study funding}

No targeted funding reported.

\section{Disclosure}

The authors report no disclosures relevant to the manuscript. Go to Neurology.org/N for full disclosures.

\begin{tabular}{|c|c|c|}
\hline \multicolumn{3}{|c|}{ Appendix Authors } \\
\hline Name & Location & Contribution \\
\hline $\begin{array}{l}\text { David } \\
\text { Dongkyung } \\
\text { Kim, MD }\end{array}$ & $\begin{array}{l}\text { Western University, } \\
\text { London, Canada }\end{array}$ & $\begin{array}{l}\text { Involved in the concept and } \\
\text { writing of the manuscript }\end{array}$ \\
\hline $\begin{array}{l}\text { Amit Kumar } \\
\text { Sharma, MD }\end{array}$ & $\begin{array}{l}\text { Western University, } \\
\text { London, Canada }\end{array}$ & $\begin{array}{l}\text { Involved in the concept and } \\
\text { writing of the manuscript }\end{array}$ \\
\hline
\end{tabular}

Appendix (continued)

\begin{tabular}{lll}
\hline Name & Location & Contribution \\
\hline $\begin{array}{l}\text { Manas } \\
\text { Sharma, MD }\end{array}$ & $\begin{array}{l}\text { Western University, } \\
\text { London, Canada }\end{array}$ & $\begin{array}{l}\text { Involved in critical revision and } \\
\text { study supervision }\end{array}$ \\
\hline $\begin{array}{l}\text { Andrea } \\
\text { Andrade, MD }\end{array}$ & $\begin{array}{l}\text { Western University, } \\
\text { London, Canada }\end{array}$ & $\begin{array}{l}\text { Involved in critical revision and } \\
\text { study supervision }\end{array}$ \\
\hline
\end{tabular}

\section{References}

1. Dracopoulos A, Widjaja E, Raybaud C, Westall CA, Snead OC III. Vigabatrinassociated reversible MRI signal changes in patients with infantile spasms. Epilepsia 2010;51:1297-1304.

2. Hussain SA, Tsao J, Li M, et al. Risk of vigabatrin-associated brain abnormalities on MRI in the treatment of infantile spasms is dose-dependent. Epilepsia 2017;58: 674-682. 


\section{Neurology}

\section{Teaching NeuroImages: Reversible neuroimaging findings during treatment of infantile spasms with vigabatrin}

David Dongkyung Kim, Amit Kumar Sharma, Manas Sharma, et al.

Neurology 2020;95;e2314-e2315 Published Online before print July 16, 2020

DOI 10.1212/WNL.0000000000010370

This information is current as of July 16, 2020

\section{Updated Information \&} Services

References

Subspecialty Collections

Permissions \& Licensing

Reprints including high resolution figures, can be found at: http://n.neurology.org/content/95/16/e2314.full

This article cites 2 articles, 0 of which you can access for free at: http://n.neurology.org/content/95/16/e2314.full\#ref-list-1

This article, along with others on similar topics, appears in the following collection(s):

All Epilepsy/Seizures

http://n.neurology.org/cgi/collection/all_epilepsy_seizures

All Pediatric

http://n.neurology.org/cgi/collection/all_pediatric

All Toxicology

http://n.neurology.org/cgi/collection/all_toxicology

Infantile spasms

http://n.neurology.org/cgi/collection/infantile_spasms

MRI

http://n.neurology.org/cgi/collection/mri

Information about reproducing this article in parts (figures,tables) or in its entirety can be found online at:

http://www.neurology.org/about/about_the_journal\#permissions

Information about ordering reprints can be found online:

http://n.neurology.org/subscribers/advertise

Neurology ${ }^{\circledR}$ is the official journal of the American Academy of Neurology. Published continuously since 1951, it is now a weekly with 48 issues per year. Copyright (C 2020 American Academy of Neurology. All rights reserved. Print ISSN: 0028-3878. Online ISSN: 1526-632X.

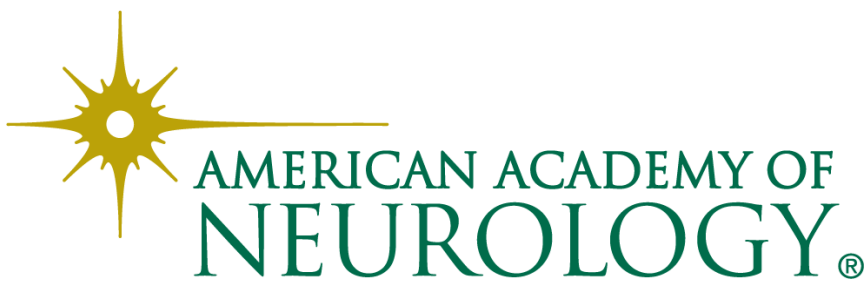

